\title{
Special issue on selected articles from 2010 Denver X-ray Conference
}

In early 2003, the Powder Diffraction journal and the Denver X-ray Conference (DXC) agreed to collaborate to publish selected DXC articles in the special issue of the Powder Diffraction journal. For the past 8 years, the annual publication of the special June issue has significantly increased the service and the number of technical articles available to the readers of this journal, as well as the circulation of the selected DXC articles for their authors.

I would like to thank the editors of the Proceedings of the 2011 DXC (or Advances in X-ray Analysis), Tom Blan- ton and George Havrilla, for recommending the articles for publication in this special issue. I also want to thank Nicole Ernst Boris, Denise Flaherty and Carly Bray of ICDD for making sure that everything was in order for this issue.

I hope that our readers will find the articles interesting and useful.

\section{9th Denver X-Ray Conference and Selected Papers for the Special June Powder Diffraction issue}

This special June issue of Powder Diffraction is comprised of selected papers presented at the 2010 59th annual Denver X-ray Conference (DXC). At DXC, 16 workshops, 2 poster sessions, and 16 special sessions were held, covering the following topics: Basic XRD, Basic XRF, XRF Sample Prep, Trace Phase Identification, Texture Analysis, 2D Detectors, Cultural Heritage, Quantitative Analysis XRF, Polymers, Pair Distribution Function, Renewable Energy, Polymers-SAXS, Instrumentation, Nanomaterials, Fusion and Industrial Applications XRF, Rietveld Analysis, Handheld XRF, X-ray Imaging, Micro Diffraction, High Resolution XRD, Stress Analysis, and Trace Analysis XRF.

As part of the Denver Conference, proceedings are published and from these proceedings, selected papers covering $\mathrm{XRD}, \mathrm{XRF}$, and other high energy scattering methods were chosen for publication in Powder Diffraction. This issue of Powder Diffraction will provide readers with the opportunity to learn about current topics in a variety of materials characterization applications.

The talents of many people are required to make this special issue possible. Besides the authors themselves, we thank the DXC Organizing Committee for their reviews of these articles. We would also like to thank the DXC Conference Coordinator Denise Flaherty, Powder Diffraction Managing Editor Nicole Ernst Boris, and Powder Diffraction Editor-in-Chief Ting Huang for all of their hard work in making this publication a reality. We hope you enjoy this publication and we look forward to seeing you at the 2011 Denver X-ray Conference in Colorado Springs, Colorado 1-5 August 2011 (www.dxcicdd.com).

Tom Blanton and George Havrilla

Eastman Kodak Co., Los Alamos National Laboratory 